\title{
Mapping the likelihood of foot-and-mouth disease introduction along the border between Brazil and Paraguay
}

\author{
Thaís Basso Amaral(1), Valery Gond(2) and Annelise Tran ${ }^{(3)}$ \\ (1)Embrapa Gado de Corte, Avenida Rádio Maia, no 830, Zona Rural, CEP 79106-550 Campo Grande, MS, Brazil. E-mail: \\ thais.amaral@embrapa.br (2)Centre de Coopération Internationale en Recherche Agronomique pour le Développement, UPR 105, \\ Biens et Services des Écosystèmes Forestiers Tropicaux, Campus de Baillarguet, TA C-105/D-214, 34398 Montpellier, France. E-mail: \\ valery.gond@cirad.fr ${ }^{(3)}$ Maison de la Télédétection en Languedoc-Roussillon, no 500, Rue Jean-François Breton, 34093 Montpellier, France. \\ E-mail: annelise.tran@cirad.fr
}

\begin{abstract}
The objective of this work was to apply fuzzy majority multicriteria group decision-making to determine risk areas for foot-and-mouth disease (FMD) introduction along the border between Brazil and Paraguay. The study was conducted in three municipalities in the state of Mato Grosso do Sul, Brazil, located along the border with Paraguay. Four scenarios were built, applying the following linguistic quantifiers to describe risk factors: few, half, many, and most. The three criteria considered to be most likely to affect the vulnerability to introduction of FMD, according to experts' opinions, were: the introduction of animals in the farm, the distance from the border, and the type of property settlements. The resulting maps show a strong spatial heterogeneity in the risk of FMD introduction. The used methodology brings out a new approach that can be helpful to policy makers in the combat and eradication of FMD.
\end{abstract}

Index terms: Aphthovirus, cloven-footed animals, FMD, multicriteria analysis, risk map.

\section{Mapeamento do risco de introdução da febre aftosa na fronteira do Brasil com o Paraguai}

Resumo - O objetivo deste trabalho foi aplicar a metodologia de análise multicritério difusa para tomada de decisões em grupo, para determinar áreas de risco de introdução da febre aftosa na fronteira do Brasil com o Paraguai. O estudo foi conduzido em três municípios do Estado do Mato Grosso do Sul, localizados na fronteira com o Paraguai. Quatro cenários foram construídos, tendo-se aplicado os seguintes quantificadores linguísticos para descrever os fatores de risco: poucos, metade, muitos e maioria. Os três critérios considerados mais prováveis de influenciar a vulnerabilidade à introdução da febre aftosa, de acordo com a opinião dos especialistas, foram: a introdução de animais na fazenda, a distância da fronteira e a existência do tipo de propriedade assentamentos. Os mapas resultantes mostram uma forte heterogeneidade espacial no risco de introdução da febre aftosa. A metodologia utilizada traz uma nova abordagem que pode auxiliar políticas públicas no combate e na erradicação da febre aftosa.

Termos para indexação: Aphtovirus, animais biungulados, FMD, análise multicritério, mapas de risco.

\section{Introduction}

Foot-and-mouth disease (FMD) is one of the most important animal diseases from an economic point of view (Paton et al., 2009; Knight-Jones \& Rushton, 2013). The foot-and-mouth disease virus (FMDV) is an Aphthovirus within the Picornaviridae family of viruses (Garland \& Donaldson, 1990). It replicates extremely rapidly, is highly contagious, and can affect a wide range of domestic and wild cloven-footed animals, which makes it one of the most infectious diseases known in the animal kingdom. The key features that contribute to this include the virus's ability to gain entry and initiate infection through a variety of sites, as well as its small infective dose, short incubation period, release before the onset of clinical signs, excretion of massive quantities by infected animals, ability to spread large distances due to airborne dispersal, and survivability in the environment (Donaldson \& Alexandersen, 2002).

In Brazil, FMD was endemic until the 1980s, when a decrease in the number of outbreaks was observed due to the use of quality vaccine and to the identification and control of endemic areas (Lyra \& Silva, 2004; Naranjo\& Cosivi, 2013). In 1992, an eradication 
program with regionalized strategies, according to livestock production systems, was implemented, leading to a decrease in outbreaks from 2001 onwards (Saraiva, 2004). According to the principle of regionalization established by the World Organisation of Animal Health (OIE), Brazil has, nowadays, 59\% of the territory classified as FMD free with vaccination, which accounts for $89 \%$ of the Brazilian bovine herd (Brasil, 2011).

Specifically in the state of Mato Grosso do Sul, 21 FMD outbreaks were recorded in 1994, 2 in 1998, and 2 in 1999, in the municipalities of Porto Murtinho and Naviraí. In 2001, the state was classified as a FMD-free zone by the OIE. However, in September 2005, there was a reintroduction of the FMD virus in the state, involving municipalities located along the border with Paraguay. This reintroduction led to the suspension of the FMD-free classification in the state and also in other states of Brazil. The restoration of the sanitary condition of free from FMD by OIE only occurred in 2008 .

In 2007, by the recommendation of the OIE, a high surveillance zone (HSZ) was created, which consists of a $15-\mathrm{km}$ area along each side of the border between Paraguay, Brazil, Argentina, and Bolivia. The implementation of this HSZ was due to the epidemiological instability observed in the region, with frequent occurrences of FMD outbreaks in border areas, but without clarifying the origin of the viral agent (Brasil, 2010). Veterinary surveillance was reinforced through several actions implemented in the region, such as geolocation of the farms and individual identification of all animals in the area. One of the biggest issues in obtaining the status of "free zone with vaccination" is maintaining this sanitary condition, because of the necessary permanent monitoring procedures.

The strategy of Ministério de Agricultura, Pecuária e Abastecimento, the Brazilian Ministry of Agriculture, Livestock and Supply, to combat and eradicate FMD is based on activities and actions that aim to identify the presence or certify the absence of a specific animal disease in a defined geographic area, with particular attention to border regions. Activities are focused towards farms more likely to contain infected or diseased animals.

The analysis of the spatial distribution of disease risk and its visual presentation through risk maps allows designing targeted and, therefore, more cost-effective animal disease surveillance strategies. Another benefit is the potential to reveal spatial heterogeneity in risk patterns at fine scales relevant for practical prevention and control activities (Eisen \& Eisen, 2011).

There are various methods by which disease risk maps can be generated. One of these is the GIS-based multicriteria decision analysis (GIS-MCDA), which can be defined as a process that transforms and combines geographical data (map criteria) and value judgments (decision-makers' preferences and uncertainties) to obtain appropriate and useful information for decision-making (Boroushaki \& Malczweski, 2010). A key strength of MCDA is the ability to incorporate multiple stakeholder perspectives, as well as uncertain, subjective, and qualitative information, into an explicit and transparent decision-making processes (Hongoh et al., 2011).

In epidemiology, GIS-MCDA has been used to identify risk areas for vector-borne diseases, in which there is a clear relationship between land cover and the presence of the vector (Rakotomanana et al., 2007), as for avian influenza (Stevens et al., 2009; Zahhaf, 2010) and for Rift Valley fever (Clements et al., 2006).

Although several models and studies have adopted GIS to evaluate epidemics and control measures, the use of GIS tools to identify potential risk areas for FMD in countries free of the disease with vaccination or in the process of eradicating the disease is still incipient. It should be highlighted that the GIS-MCDA methodology has never been applied before to map the likelihood of FMD introduction.

The objective of this work was to apply fuzzy majority multicriteria group decision-making to determine risk areas for foot-and-mouth disease (FMD) introduction along the border between Brazil and Paraguay.

\section{Materials and Methods}

The study was conducted in three sites (municipalities) located on the Brazilian side of the border, in the state of Mato Grosso do Sul, which used to be considered HSZ for FMD: Porto Murtinho in the extreme north (21 $\left.41^{\prime} 56^{\prime \prime} \mathrm{S}, 57^{\circ} 52^{\prime} 57^{\prime \prime} \mathrm{W}\right)$, Ponta Porã $\left(23^{\circ} 32^{\prime} 30^{\prime \prime} \mathrm{S}, 5^{\circ} 37^{\prime} 30^{\prime \prime} \mathrm{W}\right)$ in the center, and Mundo Novo $\left(23^{\circ} 56^{\prime} 16^{\prime \prime} \mathrm{S}, 54^{\circ} 16^{\prime} 15^{\prime \prime} \mathrm{W}\right)$ in the south of the state. These municipalities were chosen because they represent differences that exist along the border and 
are also well geographically distributed. The study was performed in 2012.

The climate of Mato Grosso do Sul is classified, according to Köppen, as tropical-type Aw, with an average temperature of $24.4^{\circ} \mathrm{C}$ in the warmest months (January and February) and of $19.1^{\circ} \mathrm{C}$ in the coldest months (June and July). The average annual precipitation is 1,470 $\mathrm{mm}$ : January is the wettest month, with an average of $243 \mathrm{~mm}$ of rain and $81 \%$ relative humidity, and August is the driest, with $40 \mathrm{~mm}$ of rain and $60 \%$ relative humidity, on average.

The municipality of Mundo Novo is the smallest site, occupying an area of 480 thousand square kilometers, with approximately 30 thousand head of cattle, and is characterized by small producers, who mainly develop dairy farming and subsistence agriculture. Ponta Porã is a 5.3-million square kilometer agricultural region, where large and family farming coexist, and around 3 thousand properties of smallholder farming systems are found. Porto Murtinho is the largest municipality, with 17.7 million square kilometers, and is mainly characterized by extensive livestock production, with a predominance of medium and large beef cattle farms, with a herd of approximately 650 thousand bovines.

By an agreement between Embrapa Gado de Corte and Ministério da Agricultura, Pecuária e Abastecimento, the official database of 2010 was used for the present study. This database contains all properties declared by the producers of each studied site, including number of cattle, herd categories, number of other species, shipments (entries and exists), geolocation, pasture area, and total area.

Delimitations of the municipalities of the state of Mato Grosso do Sul and of Paraguay, as well as the main roads of the evaluated region, were obtained from Instituto Brasileiro de Geografia e Estatística (2010); and the geolocation of slaughterhouses, auctions, and dairy plants was provided by Ministério da Agricultura, Pecuária e Abastecimento.

Geographic data were visualized and manipulated using ArcGIS, version 9.2 (ESRI, Redlands, CA, USA). The methodology applied for multicriteria decision analysis was the fuzzy majority approach implemented within ArcGIS under the Multicriteria Group Analyst extension proposed by Boroushaki \& Malczewski (2010).
This process comprises two basic steps. The first is the creation of individual solution maps for each decision-maker. Each decision-maker selects the relevant criteria for the decision-making process according to her/his judgment. Then the criteria to be maximized and minimized can be selected and standardized. The standardized values will be added to the solution map in the form of standardized fields. The last step of the individual decision-making process involves the selection of the criterion weights and of the aggregation definition term. The ordered weighted averaging (OWA) score of the alternatives will be stored in the OWA field of the solution map. The OWA analysis allows manipulation of the degree to which a high score for a criterion can compensate for a low score in another.

The second step is to generate the group solution map. The module reads the judgments and preferences of all decision-makers from the database and creates the group solution map in the form of a feature layer. The module is capable of aggregating solution maps according to different values. Problems related to group decision-making typically require computing an overall opinion of the group, which corresponds to the "majority" of the decision-makers' preferences. Within fuzzy approaches to group decision-making, a linguistic statement (e.g., most) can be used to synthesize the opinion of the majority of the decision-makers. This fuzzy majority can be defined in terms of a linguistic quantifier, which can be used to indicate a combination strategy to guide the aggregation process of an individual decision-maker's preferences.

The final score of alternatives is calculated according to the fuzzy majority approach, using induced ordered weighted averaging (Iowa), and it is then stored in a field within the group solution feature layer. The combination method generates a numeric likelihood score (OWA) that ranges from 0 (lower likelihood) to 1 (higher likelihood) for each studied feature. For a detailed explanation of the construction of OWA values, see Boroushaki \& Malczweski (2010).

The risk factors were based on the concept of "vulnerability", which means the ability of the viral agent to enter a farm or region and spread. Eight experts from universities, governmental agencies, and the OIE were invited to give their opinion on the risk factors known to be the most related to FMD introduction in the region. The experts specified their 
preferences regarding the level of importance of each risk factor (weight), represented by a set of linguistic terms: very low, low, medium, high, and very high. These linguistic terms were transformed into crisp numbers. Each linguistic term can be represented by a linear-membership fuzzy number. The use of fuzzy logic allows dealing with the uncertainty or imprecision that is inherent of complex decision-making problems. The transformation uses a three-scale system, which corresponds to the fuzzy numbers.

The linguistic quantifiers used to aggregate experts' opinions in the group solution maps were pre-established in order to explore and analyze different possible scenarios. Experts were invited to give their opinions about the importance of the different risk factors, regardless of whether they would be satisfied by few, many, half, or most of the risk indicators.

Standardization of risk factors was carried out in order to place all values on the same scale. This step is very important when dealing with parameters of different units and scales. In order to allow a comparison between them, each parameter variable ranges from 0 to 1 .

The risk factors used in the present study were identified from published literature, discussion with experts from universities and government agencies, and were converted into risk indicators (Table 1).

Data sets were subjected to four different linguistic quantifiers - few, half, many, and most - in order to aggregate the individual solution maps into the group solution maps. The final scenarios for each data set were: few, the region/farm would be at risk of vulnerability to FMD introduction if only few risk factors were present; half, the region/farm would be at risk of vulnerability to FMD introduction if half of the risk factors were present; many, the region/farm would be at risk of vulnerability to FMD introduction if many of the risk factors were present; and most, the region/ farm would be at risk of vulnerability to FMD if most of risk factors were present.

OWA values were estimated by farm. To construct risk maps for the entire study area, an interpolation in the ArcGis software, version 9.2 (ESRI, Redlands, CA, USA), was carried out using the kriging tool from the Spatial Analyst extension. This is an interpolation method that predicts unknown values from data observed at known locations. The method uses variograms to express spatial variation and minimizes the error of predicted values, which are estimated by the spatial distribution of the predicted values. A mask of the municipality was used in order to distribute values to all studied sites.

The Kruskal-Wallis nonparametric test, at $1 \%$ probability, was applied in order to compare OWA values between sites and types of property. Assumptions for the Kruskal-Wallis test are that, within each sample, the observations are independent and identically distributed, and that the samples are independent of each other, which is the case of OWA values. All statistical analyses were performed in the SAS software, version 10.0 (SAS Institute Inc., Cary, NC, USA).

\section{Results and Discussion}

It is important to clarify that this was an exercise in modeling the likelihood of FMD introduction along the border region between Brazil and Paraguay, although currently considered free with vaccination. The GIS-MCDA methodology employed does not generate estimates of absolute risk, but rather describes variation in absolute risk maps. The maps produced allow the identification of areas with relatively higher and lower risk of FMD introduction, without quantifying what the risk is, but still informing risk management activities.

As with all modeling work, it is important for the user of these outputs to be aware of the assumptions made in relation to the models, as well as of any potential sources of selection and information biases when interpreting the results of such analyses (Stevens et al., 2009). The risk indicators studied in the present work were the ones that could be mapped. Other risk factors, as, for example, movement of people within a farm and illegal shipments, could not be spatially represented.

The two criteria considered to be most likely to influence the vulnerability to FMD introduction, according to experts' opinions, were the introduction of animals in the farm (entries) and the distance from the border (Figure 1). For the criteria related to the type of production systems, the experts agreed that the type farm presents less risk than the other types (settlements, periphery, and Indian zone, in this order). Exits represented the criterion that caused most controversy among experts.

Experts' opinions are very important in this kind of exercise, in which there is a lack of empirical data 
on various aspects of the disease and its transmission. Several FMD studies are based on experts' opinions (Sanson et al., 1993; Forbes et al., 1994; Horst et al., 1999; Bates et al., 2003; Wooldridge et al., 2006; Garabed et al., 2009). In the present study, experts' opinions reached some degree of agreement: there was only one expert that had a divergent overall opinion from the others and used only extreme values to express his opinion about risk perception, giving maximum values for the criteria that he judged most important and minimum values for the others. Since the adopted methodology takes the majority of the opinions into consideration, this was not a problem.

The distance from the Paraguay border seemed to be, according to the experts, one of the most important risk factors. Although Paraguay has the same sanitary

Table 1. Factors associated with the introduction of foot-and-mouth disease (FMD) along the border between Brazil and Paraguay.

\begin{tabular}{|c|c|c|}
\hline $\begin{array}{l}\text { Potential risk factor for } \\
\text { introduction of FMD } \\
\text { (factor abbreviation) }\end{array}$ & Indicator measurement & $\begin{array}{l}\text { Hypothesized relationship between potential risk factor and FMD } \\
\text { introduction in the region }\end{array}$ \\
\hline $\begin{array}{l}\text { Cattle density } \\
\text { (heads per hectare) }\end{array}$ & $\begin{array}{l}\text { Total bovine herd divided by pasture area of } \\
\text { the farm. }\end{array}$ & $\begin{array}{l}\text { Increasing density of cattle is expected to be associated with a higher conta } \\
\text { rate between susceptible and infected animals. }\end{array}$ \\
\hline $\begin{array}{l}\text { Presence of young animals } \\
\text { (Pres0024) }\end{array}$ & $\begin{array}{l}\text { Sum of male and female cattle and buffalo } \\
\text { from } 0 \text { to } 24 \text { months of age. }\end{array}$ & $\begin{array}{l}\text { In areas where animals are subjected to routine FMD vaccinations every } \\
6 \text { months, this age group of animals, especially from } 6 \text { to } 12 \text { months, } \\
\text { represents the most susceptible to FMD because they received a lower } \\
\text { number of vaccines during their life time. }\end{array}$ \\
\hline
\end{tabular}

Presence of other susceptible species (Espsucep)

Distance from main roads (Distmainroads)

Distance from the frontier (Distfrontier)
Sum of number of other susceptible species In Brazil, only cattle and buffalo are vaccinated against FMD. If the virus is present on the farm, such as goats, sheep, able to enter in a region, these other species would be affected. and pigs.

Euclidian distance from the farm to the Mains roads for the circulation of most of the animals that are transported to nearest main road of the region (paved or in slaughterhouses, auctions, or to other farms. the process of paving).

Euclidian distance from the farm to the Being an airborne disease, increasing the distance from the border with lower border with another country or region with a sanitary conditions is expected to be associated with decreasing the risk of lower sanitary status.
Distance from slaughter houses Euclidian distance from the farm to the and dairy plants (Distslaughter) nearest slaughter house or dairy plant.

Distance from auctions and rest Euclidian distance from the farm to the zones (Distauctions)

Animal shipments (Entries)

Animal shipments (Exits)

Type of property

(Settlements)

(Periphery)

(Indian zone)

(Farm) nearest auction or area designated for the rest of the animals in transit.

Number of cattle shipments that enter in the farm in a one year period.

Number of cattle shipments that leave the farm in a one year period.
FMD introduction.

Since they represent animal agglomeration from different locations, the proximity of these areas is expected to be associated with higher risk. Milk transport to dairy plants is also considered a vehicle of FMD transmission.

Since they represent animal agglomeration from different locations, the proximity of these areas is expected to be associated with higher risk. Milk transport to dairy plants is also considered a vehicle of FMD transmission.

${ }^{(1)}$ Settlements, area of land under agrarian reform, used for agriculture and/or extractive production. It is also a space of heterogeneous social groups, consisting of peasant families, who earn their living in expropriated or purchased areas by the federal and/or the state government. ${ }^{(2)}$ Periphery, small farms located on the outskirts or even inside the cities. ${ }^{(3)}$ Indian zone, farms located inside Indian zones. ${ }^{(4)}$ Rural property, areas designated to livestock or agriculture activities, independently of their size, and that do not fit in the other three categories.

This is a qualitative variable. The properties Risk perception is more subjective in this indicator. According to experts' in the database are characterized as: settlements ${ }^{(1)}$, periphery ${ }^{(2)}$, Indian zone ${ }^{(3)}$, and rural property ${ }^{(4)}$. opinions, settlements, periphery, and Indian zone would present higher risk of FMD introduction than a rural property. This is specially due to the higher cattle density in these areas, especially in settlements, and to the lower perceived sanitary conditions of these establishments.
Exits of animals from the farms are expected to be associated with the risk of FMD introduction due to the circulation of vehicles and of people to transport these animals.

activities, independently of their size, and that do not fit in the other three categories. 
status as Brazil, i.e., free with vaccination, and the Paraguayan government has been making efforts to improve sanitary conditions in the country, the situation has not totally been resolved. In the end of 2011, an outbreak occurred in Paraguay (World Organisation for Animal Health, 2012), showing that there is still some fragility in the control and eradication of FMD, especially in some isolated areas. A study published by Garabed et al. (2009) also identified great divergence between experts' opinions and the OIE classification about the probability of FMD presence in Paraguay, even though it is currently considered free.

For the type of property, experts agreed that settlements represent higher risk, followed by periphery and farms. This is mostly due to the generally low education level and greater need for government assistance within settlements, especially because a great part of these establishments is located along border areas. When farm-based scenarios were analyzed, the Ponta Porã site presented higher average risk values than the other sites for all scenarios. This is because $86 \%$ of the establishments from Ponta Porã are settlements. As these risk factors were considered high or very high by almost all experts, the weight of this indicator in the final risk value was also high. In
Porto Murtinho, however, settlements represent only $23 \%$ of the establishments, which results in lower risk values than those of the other municipalities. The studied sites differ from the other regions of the state of Mato Grosso do Sul, regarding some socioeconomic and geographic aspects. In addition, the great quantity of familiar establishments along this wide border makes sanitary control difficult. This is the reason why the border region between Brazil and Paraguay is one of the most critical areas for Brazilian livestock production, where the risks involved for the entry of FMD are high.

Farmers from the Mundo Novo and Porto Murtinho sites, independently of herd size, are more conscious about their role in FMD control. Despite efforts made by the government to improve sanitary measures and control, better assistance is still necessary, especially for small farmers. They still lack formal sanitary control and need constant training and support.

Following the 2005 outbreak, some lessons were learned and Paraguay and Brazil have been working together for the control and eradication of FMD. The creation of the HSZ in this area contributed to better sanitary control, and the supervision of vaccination improved vaccine coverage. Despite the end of the HSZ and the classification of the region as FMD free

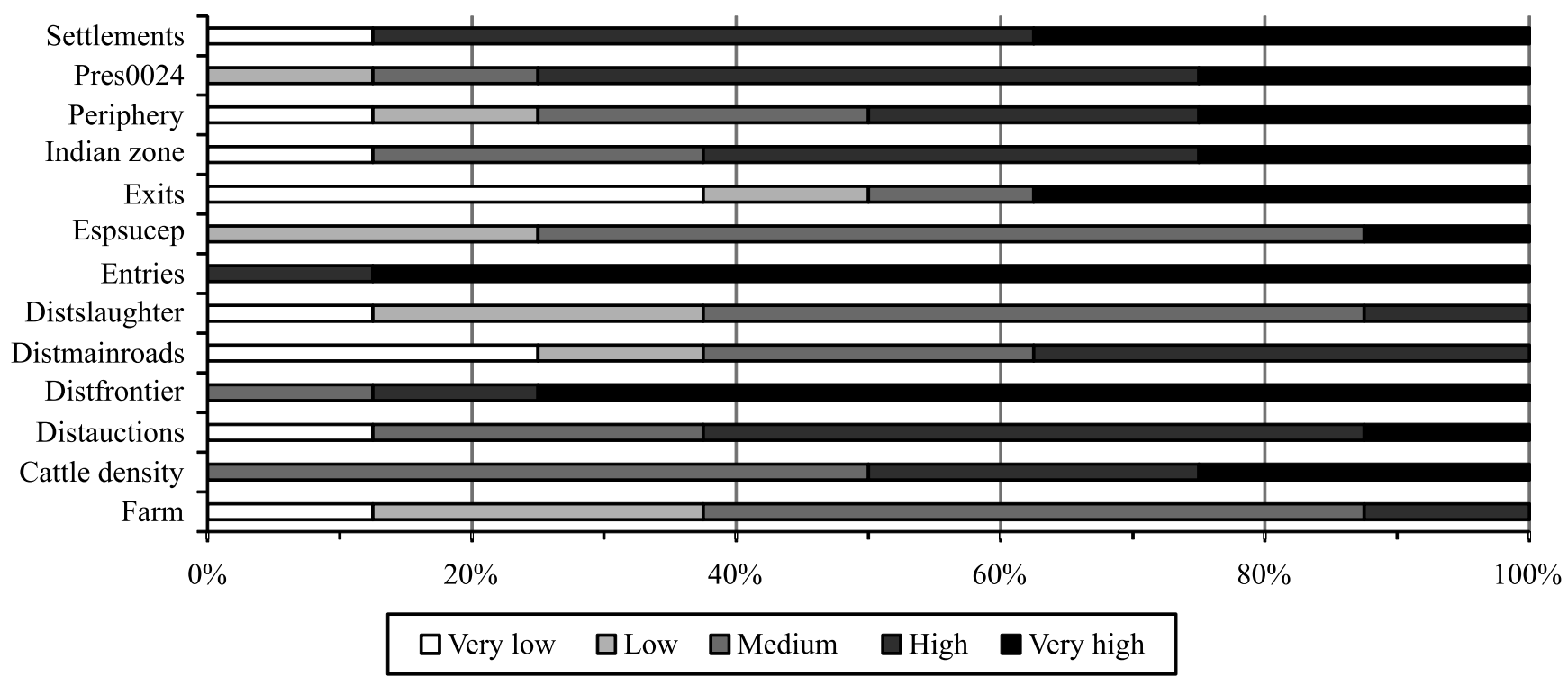

Figure 1. Risk proportion per factor according to experts' opinions. Press0024, presence of young animals; Espsucep, presence of other susceptible species; Distslaughter, distance from slaughter houses and dairy plants; Distmainroads, distance from mains roads; Distfronteir, distance from the frontier; and Distauctions, distance from auctions and rest zones. 
with vaccination, as the rest of the state of Mato Grosso do Sul, differentiated sanitary measures and control should still continue.

The fuzzy majority approach for GIS-MCDA applied in the present study provides a new framework for studying the likelihood of FMD introduction along the border between Brazil and Paraguay, which could be used to support surveillance actions in the region. This is the first time that this methodology has been applied for risk assessment of infectious animal diseases. Through the fuzzy majority approach, it was possible to combine experts' opinions and construct scenarios that can be analyzed afterwards. The question addressed here was: "For a farm to be considered at risk of FMD introduction, how many risk factors should be present? A few, half, many, or most of them?"

Risk maps were produced for the two extreme scenarios, i.e., few and most (Figures 2 and 3). The few scenario is very sensitive, and the most scenario very specific. Values are presented as OWA and range between 0 (lower likelihood) and 1 (higher likelihood); this range varies according to the studied scenario (Table 2). Resulting maps show a spatial heterogeneity of risk within each site and between sites. They identify the areas where FMD is most likely to be introduced based on the risk factors considered. The numerical value has no absolute likelihood

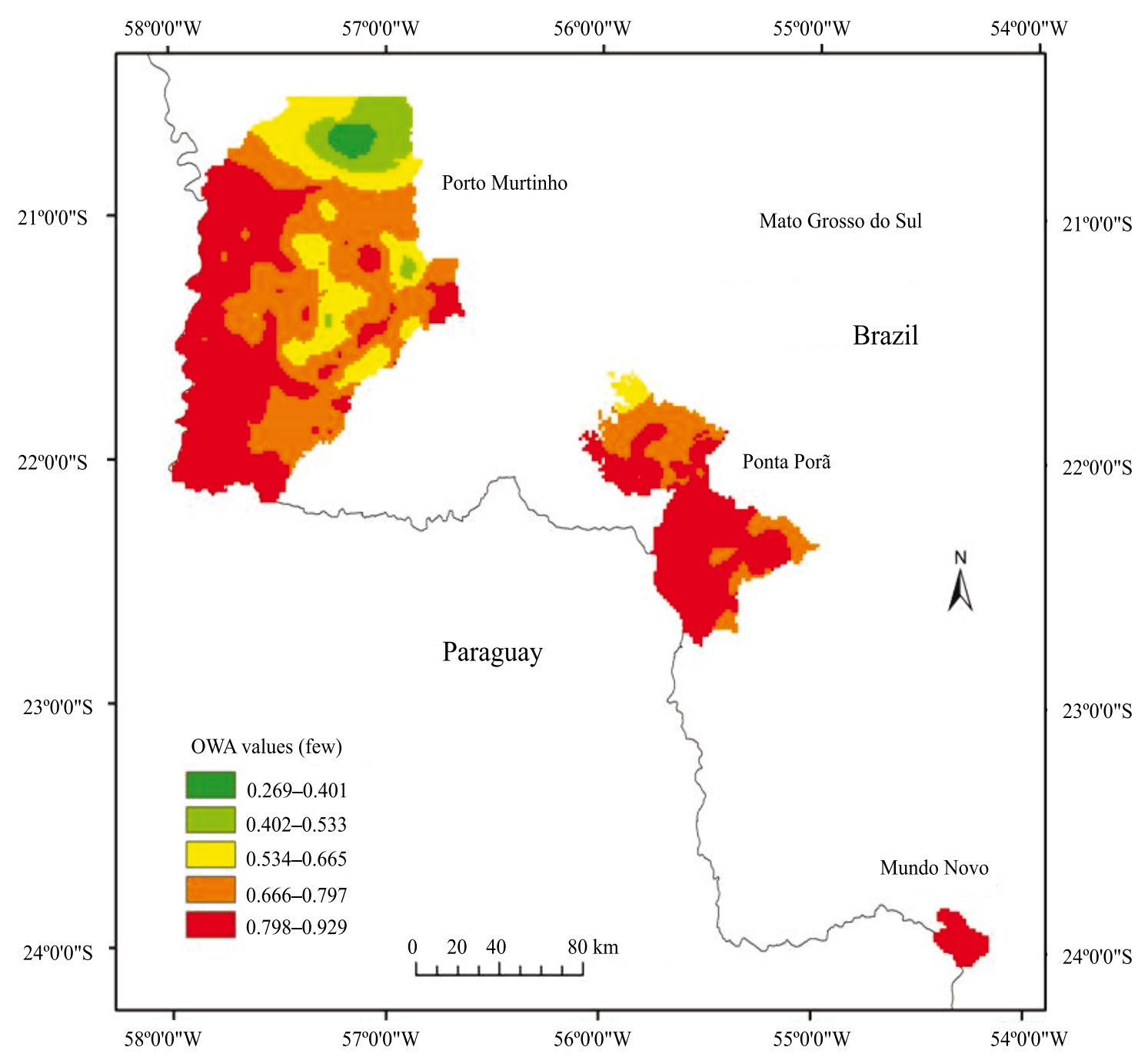

Figure 2. Foot-and-mouth disease risk map for the few scenario for the three municipalities evaluated in the state of Mato Grosso do Sul, Brazil. OWA, ordered weighted averaging. 
interpretation but rather a relative likelihood one, allowing characterization of locations with relatively lower or higher likelihood.

The likelihood of FMD introduction in the few scenario is fairly homogeneous across the Mundo Novo site, where the entire area presented high OWA values (Figure 2). For the Ponta Porã site, only the northern portion would have less risk, whereas, for the Porto Murtinho site, it is apparent that the likelihood is higher toward the western region, closer to the border.

The likelihood of FMD introduction in the most scenario is low and very low across all three sites (Figure 3), although there are some pockets of increased likelihood of FMD introduction in the southern and northern portions of the Porto Murtinho site and in the center of the Ponta Porã site.
The construction of different scenarios allowed different alternatives to be explored and selected depending on the objective of the risk assessment. The few scenario is the most sensitive, whereas the most scenario is the most specific, and the remaining two scenarios are found in between these two extremes. If the purpose of the study is to identify potential risk areas for the introduction of FMD to begin or change the direction of a surveillance program, then few or half scenarios should be used.

However, if the aim is to identify farms that have a higher potential risk of FMD introduction and to orient target surveillance actions (for example, studies of viral circulation), it would be interesting to choose farms with high OWA values in the many or most scenarios. Even if the OWA values are low (between 0 and 0.3 ), since they describe variation in absolute values, it is

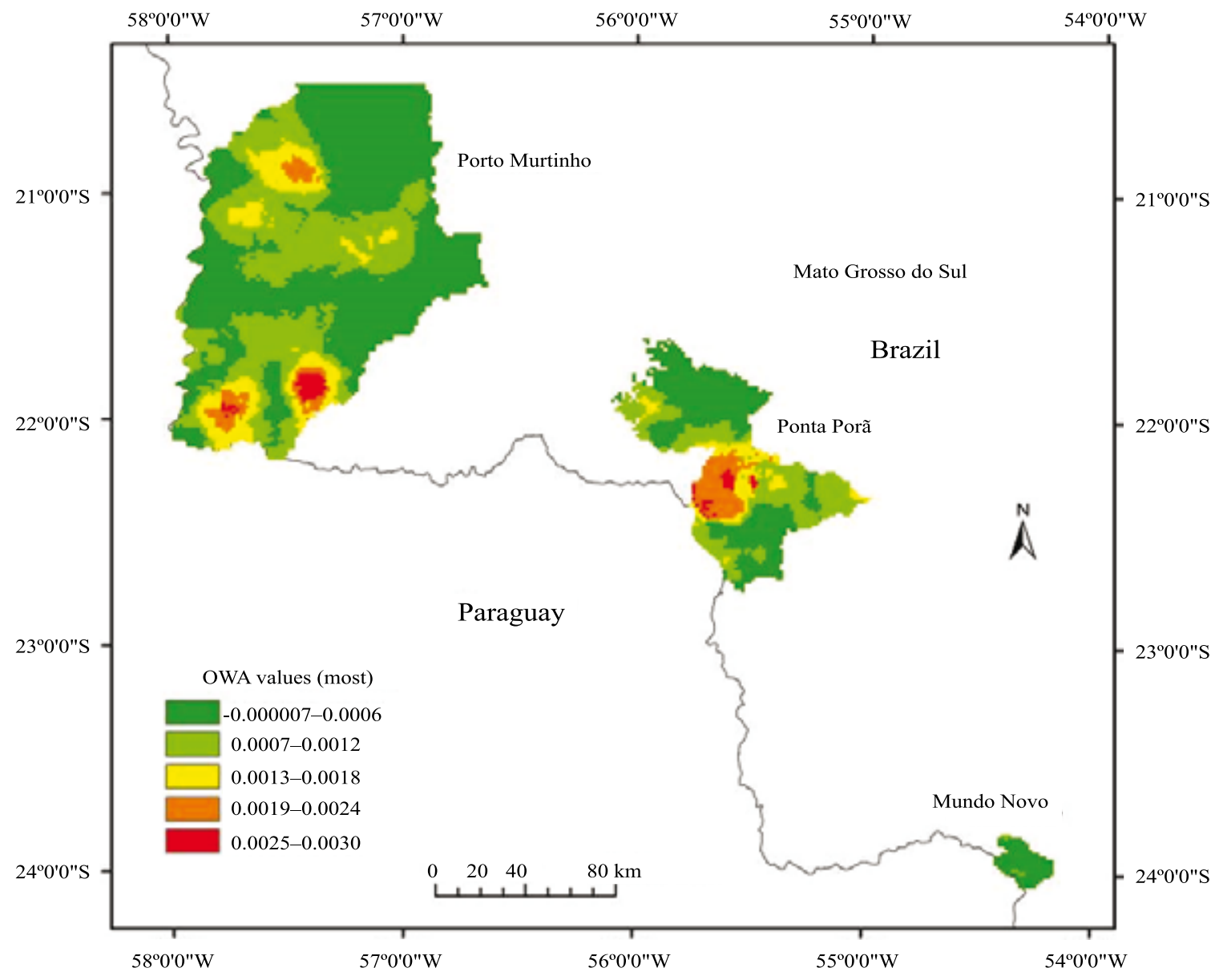

Figure 3. Foot-and-mouth disease risk maps for the most scenario for the three municipalities evaluated in the state of Mato Grosso do Sul, Brazil. OWA, ordered weighted averaging. 
possible to say that all farms with the highest values in the many and most scenarios show higher risks, because they associate almost all important risk factors, according to experts' opinions.

When the average OWA values for the three sites were compared, it was possible to observe that Ponta Porã presented a higher likelihood of FMD introduction for all studied scenarios. The order of the second and third place changes according to the assessed scenarios. Mundo Novo comes in second for the few and half scenarios, and Porto Murtinho presents the second highest values for the many and most scenarios (Table 3).

Table 2. Ordered weighted averaging (OWA) range (minimum and maximum) for different scenarios, represented by four linguistic quantifiers: few, half, many, and most.

\begin{tabular}{lcc}
\hline Scenario & Minimum & Maximum \\
\hline Few & 0.269 & 0.929 \\
Half & 0.075 & 0.563 \\
Many & 0.016 & 0.343 \\
Most & -0.000007 & 0.0030 \\
\hline
\end{tabular}

Table 3. Average ordered weighted averaging (OWA) values for the three municipalities evaluated in the state of Mato Grosso do Sul, Brazil, according to different scenarios, represented by four linguistic quantifiers: few, half, many, and most $^{(1)}$.

\begin{tabular}{lcccc}
\hline Sites & Few & Half & Many & Most \\
\hline Mundo Novo & $0.863 \mathrm{~b}$ & $0.286 \mathrm{c}$ & $0.093 \mathrm{c}$ & $0.0002 \mathrm{c}$ \\
Ponta Porã & $0.902 \mathrm{a}$ & $0.414 \mathrm{a}$ & $0.192 \mathrm{a}$ & $0.0017 \mathrm{a}$ \\
Porto Murtinho & $0.809 \mathrm{c}$ & $0.278 \mathrm{~b}$ & $0.103 \mathrm{~b}$ & $0.0006 \mathrm{~b}$ \\
\hline
\end{tabular}

${ }^{(1)}$ Means followed by equals letters, within the columns, do not differ according to the Kruskal-Wallis test, at $1 \%$ probability.

Table 4. Average ordered weighted averaging (OWA) values according to the type of property in the different scenarios, represented by four linguistic quantifiers: few, half, many, and $\operatorname{most}^{(1)}$.

\begin{tabular}{lcccc}
\hline Type of property & Few & Half & Many & Most \\
\hline Settlements & $0.904 \mathrm{a}$ & $0.431 \mathrm{a}$ & $0.197 \mathrm{a}$ & $0.0019 \mathrm{a}$ \\
Periphery & $0.891 \mathrm{~b}$ & $0.388 \mathrm{~b}$ & $0.167 \mathrm{~b}$ & $0.0009 \mathrm{~b}$ \\
Farms & $0.823 \mathrm{c}$ & $0.273 \mathrm{c}$ & $0.092 \mathrm{c}$ & $0.0003 \mathrm{c}$ \\
\hline
\end{tabular}

${ }^{(1)}$ Means followed by equals letters, within the columns, do not differ according to the Kruskal-Wallis test, at $1 \%$ probability.
The analysis by the type of property shows that, independently of the studied site, settlements present higher risk values, followed by periphery and farms, regardless of the scenario (Table 4). The Indian zone did not enter the analysis because there were only two establishments that were described as Indian zone in the data base.

In general, the risk maps produced in the present study can be used as a basis for a discussion with local stakeholders. Risk maps, associated to local knowledge, can provide an improvement in the identification of farms with potential risks and provide results that are closer to reality, helping policy makers in the combat and eradication of FMD.

\section{Conclusions}

1. The three criteria considered to be most likely to influence the vulnerability to foot-and-mouth disease (FMD) introduction, according to experts' opinions, are the introduction of animals in the farm, the distance from the border, and the type of property settlements.

2. The maps produced present differences in the likelihood of FMD introduction between the three evaluated municipalities, of which Ponta Porã shows the highest risk values in all four different studied scenarios.

3. The fuzzy majority multicriteria group decision-making analysis methodology shows great potential for studying complex diseases, such as FMD, as it deals with the uncertainty and complexity of different points of view.

\section{Acknowledgments}

To Université Laval, to Ministério da Agricultura, Pecuária e Abastecimento (Mapa), and to Centre de Coopération Internationale en Recherche Agronomique pour le Développement (Cirad), for support.

\section{References}

BATES, T.W.; THURMOND, M.C.; CARPENTER, T.E. Description of an epidemic simulation model for use in evaluating strategies to control an outbreak of foot-and-mouth disease. American Journal of Veterinary Research, v.64, p.195-204, 2003. DOI: 10.2460/ajvr.2003.64.195.

BOROUSHAKI, S.; MALCZEWSKI, J. Using the fuzzy majority approach for GIS-based multicriteria group decision-making. 
Computers \& Geosciences, v.36, p.302-312, 2010. DOI: 10.1016/j.cageo.2009.05.011.

BRASIL. Ministério da Agricultura, Pecuária e Abastecimento. Solicitação de restituição do reconhecimento da condição sanitária de zona livre de febre aftosa com vacinação: zona de zlta vigilância do Estado de Mato Grosso do Sul. Brasília: Departamento de Saúde Animal, 2010.

BRASIL. Ministério da Agricultura, Pecuária e Abastecimento. Zona livre de febre aftosa, com reconhecimento da OIE. Brasília: Ministério da Agricultura, Pecuária e Abastecimento, 2011. Disponível em: <http://www.agricultura.gov.br/arq_editor/ file/Mapa_OIE_2011.pdf>. Acesso em: 31 jul. 2012.

CLEMENTS, A.C.A.; PFEIFFER, D.U.; MARTIN, V. Application of knowledge-driven spatial modelling approaches and uncertainty management to a study of Rift Valley fever in Africa. International Journal of Health Geographics, v.5, p.57, 2006. DOI: $10.1186 / 1476-072 X-5-57$.

DONALDSON, A.I.; ALEXANDERSEN, S. Predicting the spread of foot and mouth disease by airborne virus. Revue Scientifique et Technique de l'Office International des Epizooties, v.21, p.569-575, 2002.

EISEN, L.; EISEN, R.J. Using geographic information systems and decision support systems for the prediction, prevention, and control of vector-borne diseases. Annual Review of Entomology, v.56, p.41-61, 2011. DOI: 10.1146/annurev-ento-120709-144847.

FORBES, R.N.; SANSON, R.L.; MORRIS, R.S. Application of subjective methods to the determination of the likelihood and consequences of the entry of foot-and-mouth disease into New Zealand. New Zealand Veterinary Journal, v.42, p.81-88, 1994. DOI: $10.1080 / 00480169.1994 .35792$.

GARABED, R.B.; PEREZ, A.M.; JOHNSON, W.O.; THURMOND, M.C. Use of expert opinion for animal disease decisions: an example of foot-and-mouth disease status designation. Preventive Veterinary Medicine, v.92, p.20-30, 2009. DOI: 10.1016/j.prevetmed.2009.06.010.

GARLAND, A.J.M.; DONALDSON, A.I. Foot-and-mouth disease. Surveillance, v.17, p.6-8, 1990.

HONGOH, V.; HOEN, A.G.; AENISHAENSLIN, C.; WAAUB, J-P.; BELANGER, D.; MICHEL, P. Spatially explicit multi-criteria decision analysis for managing vector-borne diseases. International Journal of Health Geographics, v.10, p.70, 2011. DOI: $10.1186 / 1476-072 X-10-70$.

HORST, H.S.; DIJKHUIZEN, A.A.; HUIRNE, R.B.M.; MEUWISSEN, M.P.M. Monte Carlo simulation of virus introduction into the Netherlands. Preventive Veterinary Medicine, v.41, p.209-229, 1999. DOI: 10.1016/S0167-5877(99)00038-0.

INSTITUTO BRASILEIRO DE GEOGRAFIAE ESTATÍSTICA. Downloads: geociências. Disponível em: <http://downloads. ibge.gov.br/downloads_geociencias.htm>. Acesso em: 13 maio 2010 .
KNIGHT-JONES, T.J.D.; RUSHTON, J. The economic impacts of foot and mouth disease - What are they, how big are they and where do they occur? Preventive Veterinary Medicine, v.112, p.161-173, 2013. DOI: 10.1016/j.prevetmed.2013.07.013.

LYRA, T.M.P.; SILVA, J.A. A febre aftosa no Brasil, 1960-2002. Arquivo Brasileiro de Medicina Veterinária e Zootecnia, v.56, p.565-576, 2004. DOI: 10.1590/S0102-09352004000500001.

NARANJO, J.; COSIVI, O. Elimination of foot-and-mouth disease in South America: lessons and challenges. Philosophy Transactions the Royal Society B: Biological Sciences, v.368, p. 20020381, 2013. DOI: 10.1098/rstb.2012.0381.

PATON, J.D.; SUMPTION, K.J.; CHARLESTON, B. Options for control of foot-and-mouth disease: knowledge, capability and policy. Philosophical Transactions of the Royal Society B: Biological Sciences, v.364, p.2657-2667, 2009. DOI: 10.1098/ rstb.2009.0100.

RAKOTOMANANA, F.; RANDREMANANA, R.V.; RABARIJAONA, L.P.; DUCHEMIN, J.B.; RATOVONJATO, J.; ARIEY, F.; RUDANT, J.P.; JEANNE, I. Determining areas that require indoor insecticide spraying using Multi Criteria Evaluation, a decision-support tool for malaria vector control programs in the Central Highlands of Madagascar. International Journal of Health Geographics, v.6,p.1-11, 2007. DOI: 10.1186/1476-072X-6-2.

SANSON R.L.; MORRIS R.S.; STERN, M.W. EpiMAN: a spatial decision support system for use in an exotic disease emergency. Agricultural Systems and Information Technology Newsletter, v.5, p.20-22, 1993.

SARAIVA, V. Foot-and-mouth disease in the Americas: epidemiology and ecologic changes affecting distribution. Annals of the New York Academy of Sciences, v.1026, p.73-78, 2004. DOI: 10.1196/annals.1307.009.

STEVENS, K.B.; COSTARD, S.; MÉTRAS, R.; PFEIFFER, D.U. Mapping the likelihood of introduction and spread of highly pathogenic avian influenza virus H5N1 in Africa, Ghana, Ethiopia, Kenya and Nigeria using multicriteria decision modeling. [Washington]: International Food Policy Research Institute, 2009. Available at: <http://www.ifpri.org/ sites/default/files/publications/hpaiwp_africa.pdf $>$. Accessed on: 2 Sept. 2012.

WOOLDRIDGE, M.; HARTNETT, E.; COX, A.; SEAMAN, M. Quantitative risk assessment case study: smuggled meats as disease vectors. Revue Scientifique et Technique de l'Office International des Epizooties, v.25, p.105-117, 2006.

WORLD ORGANISATION FOR ANIMAL HEALTH. Paraguay: follow-up report $n^{\circ}$ 1. 2012. Available at: <http:// www.oie.int/wahis_2/public/wahid.php/Reviewreport/ Review?reportid=114711>. Accessed on: 14 Jan. 2016.

ZAHHAF, A. Cartographie du risque de H5N1 en Asie du Sud Est par la méthode MCDM: le cas de la Thailande. Montpellier: École Pratique des Hautes Études, 2010. 